\title{
Extended convergence of Gauss-Newton's method and uniqueness of the solution
}

\section{IoAnNis K. Argyros, YeOl Je Cho and SAnthosh GeOrge}

\section{ABSTRACT.}

The aim of this paper is to extend the applicability of the Gauss-Newton's method for solving nonlinear least squares problems using our new idea of restricted convergence domains. The new technique uses tighter Lipschitz functions than in earlier papers leading to a tighter ball convergence analysis.

\section{REFERENCES}

[1] Amat, S., Hernández, M. A. and Romero, N., Semilocal convergence of a sixth order iterative method for quadratic equations, Applied Numerical Mathematics, 62 (2012), 833-841

[2] Argyros, I. K., Cho, Y. J. and Hilout, S.,Numerical methods for equations and its applications, CRC Press, Taylor and Francis, New York, 2012

[3] Argyros, I. K., Cho, Y. J. and George, S., Local convergence for some third-order iterative methods under weak conditions, J. Korean Math. Soc., 53 (2016), No. 4, 781-793

[4] Argyros, I. K. and Magreñán, A. A., Iterative Algorithms I, Nova Science Publishers Inc., New York, 2016

[5] Argyros, I. K. and Magreñan, A. A., Iterative methods and their dynamics with applications, CRC Press, New York, 2017

[6] Argyros, I. K. and Magreñán, A. A., Iterative Algorithms II, Nova Science Publishers Inc., New York, 2017

[7] Chen, J. and Li, W., Convergence of Gauss-Newton's method and uniqueness of the solution, Appl. Math. Comput., 170 (2005), 687-705

[8] Haubler, W. M., A Kantorovich convergence analysis for the Gauss-Newton method, Numer. Math., 48 (1986), $119-125$

[9] Magreñán, A. A., Different anomalies in a Jarratt family of iterative root finding methods, Appl. Math. Comput., 233 (2014), 29-38

[10] Magreñán, A. A., A new tool to study real dynamics: The convergence plane, Appl. Math. Comput., 248 (2014), 29-38

[11] Ortega, M. and Rheinboldt, W. C., Iterative solution of nonlinear equations in several variables, Academic Press, New York, 1970

[12] Stewart, G. W., On the continuity of the generalized inverse, SIAM J. Math., 17 (1960), 33-45

[13] Smale, S., Newton's method estimates from data at one point in: R Ewing, K. Gross, C. Martin (Eds). The merging of disciplines: New directions in Pure Applied and Computational Mathematics, Springer, New York, 1886, 185-196

[14] Traub, J. F. and Wozniakowski, H., Convergence and complexity of Newton iteration, J. Assoc. Comput. Math., 29 (1979), 250-258

[15] Wang, X., Convergence of Newton's method and uniqueness of the solution of equations in Banach space, IMA J. Numer. Anal., 20 (2000), 123-134

\author{
Department of Mathematical Sciences \\ CAMERON UNIVERSITY \\ LAWTON, OK 73505, USA \\ E-mail address: iargyrosecameron.edu
}

Received: 08.08.2017; In revised form: 13.03.2018; Accepted: 20.03.2018

2010 Mathematics Subject Classification. 65G99, 65H10, 47H17, 49M15.

Key words and phrases. Gauss-Newton's method, least squares problems, Ball convergence, Lipschitz condition.

Corresponding author: Ioannis K. Argyros;iargyros@cameron.edu 
DePartment of MATHEMATICS EDUCATION AND THE RINS

GYEONGSANG NATIONAL UNIVERSITY

JINJU 660-701, KOREA

E-mail address: y jcho@gnu. ac.kr

DEPARTMENT OF MATHEMATICAL AND COMPUTATIONAL SCIENCES

NIT KARNATAKA, INDIA-575 025

E-mail address: sgeorge@nitk.ac. in 